\title{
The Differential Expression of Aqueous Soluble Proteins in Breast Normal and Cancerous Tissues in Relation to Stage and Grade of Patients
}

\author{
Seng Liang, ${ }^{1}$ Manjit Singh, ${ }^{2}$ and Lay-Harn Gam ${ }^{1}$ \\ ${ }^{1}$ School of Pharmaceutical Sciences, Science University of Malaysia, USM, 11800 Penang, Malaysia \\ ${ }^{2}$ Department of Surgery, Penang General Hospital, Jalan Residensi, Georgetown, 10990 Penang, Malaysia
}

Correspondence should be addressed to Lay-Harn Gam, layharn@usm.my

Received 3 June 2010; Revised 5 August 2010; Accepted 11 October 2010

Academic Editor: Anne Hamburger

Copyright (C) 2010 Seng Liang et al. This is an open access article distributed under the Creative Commons Attribution License, which permits unrestricted use, distribution, and reproduction in any medium, provided the original work is properly cited.

\begin{abstract}
Breast cancer is a leading cause of female deaths worldwide. In Malaysia, it is the most common form of female cancer while Infiltrating ductal carcinoma (IDC) is the most common form of breast cancer. A proteomic approach was used to identify changes in the protein profile of breast cancerous and normal tissues. The patients were divided into different cohorts according to tumour stage and grade. We identified twenty-four differentially expressed hydrophilic proteins. A few proteins were found significantly related to various stages and grades of IDC, amongst which were SEC13-like 1 (isoform b), calreticulin, 14-3-3 protein zeta, and 14-3-3 protein eta. In this study, we found that by defining the expression of the proteins according to stages and grades of IDC, a significant relationship between the expression of the proteins with the stage or grade of IDC can be established, which increases the usefulness of these proteins as biomarkers for IDC.
\end{abstract}

\section{Introduction}

Breast cancer is the major form of female cancer that is responsible for 548,000 deaths or $7 \%$ of all cancer deaths in women $[1,2]$. In Malaysia, breast cancer is the most common form of cancer in all age groups of women [3] and Infiltrating ductal carcinoma (IDC) is the most common form of breast cancer that made up $\sim 85 \%$ of all breast cancer cases [4]. Over these years, progress has been made on the study of molecular pathways, including the roles of hormones and receptors in cancer development and progression. However, the exact roles these molecules play in breast cancer growth remain inconclusive and poorly understood $[5,6]$. Therefore, identifying the differentially expressed proteins in breast cancer would be useful in understanding how the disease forms and advances. Identification of these proteins would also enable treatments that are specific to breast cancer to be formulated.

Proteomics is a large-scale study of the proteome, which is the entire compliment of expression of proteins by a living organism [7]. Proteomics uses tools such as two-dimensional polyacrylamide gel electrophoresis (2D-PAGE) and liquid chromatography/mass spectrometry (LC/MS) [8] for protein separation and analysis, respectively. This approach has been used to identify protein biomarkers in breast cancers [9-13] and other types of cancer [14-17]. Identification of protein biomarkers may have important prognostic values in the diagnosis and treatment of the disease [18, 19].

The classification and prognosis of breast cancer are based on stage and grade of the tumour $[20,21]$. Both the information for grade and stage of the cancer are used to plan treatment for the patient. In this study, we aim to identify the differentially expressed aqueous soluble proteins between cancerous and normal IDC breast tissues and to relate the expression of these proteins to the grade and stage of IDC. We believe this information will contribute to the prognosis of IDC breast cancer.

\section{Methods}

2.1. Breast Cancer Patients. Breast cancer patients were diagnosed with IDC and had undergone surgical treatment 

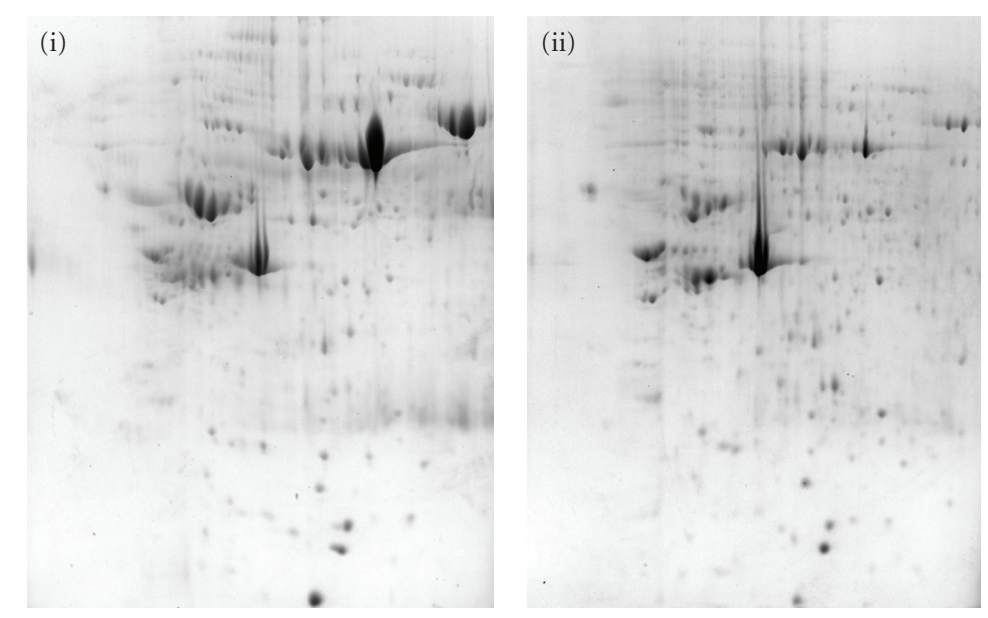

(a)
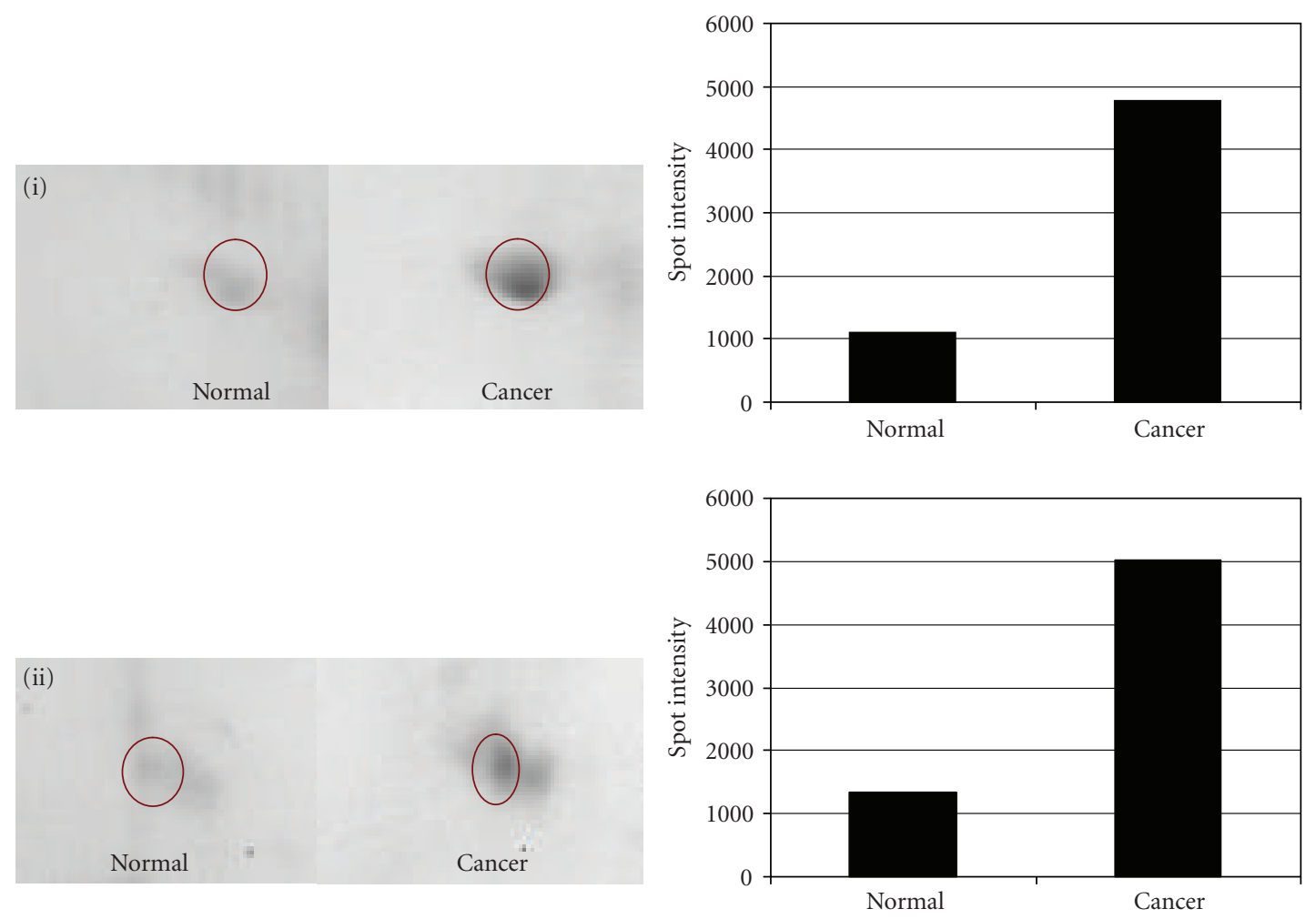

(b)

FIGURe 1: (a) 2D gel image of TRIS extract from (i) normal and (ii) cancer breast tissues of same patient. (b) Protein spot intensity of (i) calreticulin and (ii) 14-3-3 protein zeta from normal and cancerous tissue of same patient.

at Penang General Hospital, Penang, Malaysia. The patients were divided by stage and grade into 4 cohorts; Stages II, III and Grades II, III, respectively. Stage II, III cohorts contained 7 patients and 10 patients, respectively while Grade II and III cohorts contained 7 patients and 9 patients, respectively. Each sample set comprised cancerous and normal tissues from the same patient. The tissues were confirmed as cancerous and normal, respectively, by the hospital's pathologist. The information on patients' age, stage, TNM, grade, estrogen receptor, progesterone receptor, and C-ERB-B ${ }_{2}$ oncoprotein status is listed in Table 1.
2.2. Tissue Samples. Human ethical clearance from the Human Ethical Clearance Committee of Universiti Sains Malaysia and the Ministry of Health, Malaysia was received prior to conducting the study. Normal and cancerous breast tissues samples from IDC patients were obtained from the Penang General Hospital, Penang, Malaysia. Informed consents from the breast cancer patients were received before the tissues were collected. The breast tissues were pathologically confirmed by the hospital's pathologists. Breast carcinoma tumour tissues were taken from the ductal epithelium. Frozen section of tissue morphology was taken 
TABLE 1: Patient information.

\begin{tabular}{lccccccc}
\hline Patient no. & Age & Stage & $\mathrm{TNM}_{2}$ & Grade & Estrogen receptor & Progesterone receptor & C-ERB- $\mathrm{B}_{2}$ oncoprotein \\
\hline 1 & 54 & 3 & $\mathrm{~T}_{2} \mathrm{~N}_{1} \mathrm{M}_{x}$ & 1 & Positive & Positive & Negative \\
2 & 67 & 2 & $\mathrm{~T}_{2} \mathrm{~N}_{0} \mathrm{M}_{x}$ & 3 & Negative & Negative & Negative \\
3 & 60 & 3 & $\mathrm{~T}_{2} \mathrm{~N}_{1} \mathrm{M}_{x}$ & 2 & Positive & Positive & Positive \\
4 & 74 & 3 & $\mathrm{~T}_{2} \mathrm{~N}_{1} \mathrm{M}_{x}$ & 2 & Positive & Positive & Negative \\
5 & 67 & 3 & $\mathrm{~T}_{3} \mathrm{~N}_{1} \mathrm{M}_{x}$ & 2 & Negative & Negative & Positive \\
6 & 78 & 3 & $\mathrm{~T}_{4} \mathrm{~N}_{1} \mathrm{M}_{x}$ & 3 & Positive & Positive & Negative \\
7 & 64 & 3 & $\mathrm{~T}_{3} \mathrm{~N}_{1} \mathrm{M}_{x}$ & 3 & Negative & Negative & Positive \\
8 & 63 & 2 & $\mathrm{~T}_{2} \mathrm{~N}_{0} \mathrm{M}_{x}$ & 3 & Positive & Negative & Positive \\
9 & 65 & 2 & $\mathrm{~T}_{2} \mathrm{~N}_{1} \mathrm{M}_{x}$ & 3 & Negative & Negative & Negative \\
10 & 59 & 2 & $\mathrm{~T}_{2} \mathrm{~N}_{1} \mathrm{M}_{x}$ & 3 & Negative & Negative & Negative \\
11 & 55 & 4 & $\mathrm{~T}_{4} \mathrm{~N}_{x} \mathrm{M}_{1}$ & 3 & Positive & Negative & Negative \\
12 & 72 & 2 & $\mathrm{~T}_{2} \mathrm{~N}_{0} \mathrm{M}_{x}$ & 2 & Positive & Negative & Negative \\
13 & 80 & 3 & $\mathrm{~T}_{3} \mathrm{~N}_{1} \mathrm{M}_{x}$ & 2 & Positive & Positive & Negative \\
14 & 60 & 2 & $\mathrm{~T}_{2} \mathrm{~N}_{1} \mathrm{M}_{x}$ & 3 & Negative & Negative & Negative \\
15 & 62 & 2 & $\mathrm{~T}_{2} \mathrm{~N}_{1} \mathrm{M}_{x}$ & 3 & Negative & Negative & Positive \\
16 & - & 3 & $\mathrm{~T}_{4 B} \mathrm{~N}_{1} \mathrm{M}_{x}$ & 1 & Positive & Positive & Positive \\
17 & 54 & 3 & $\mathrm{~T}_{2} \mathrm{~N}_{2} \mathrm{M}_{x}$ & 2 & Negative & Negative & Negative \\
18 & 64 & 3 & $\mathrm{~T}_{3} \mathrm{~N}_{0} \mathrm{M}_{x}$ & 2 & Positive & Positive & Negative \\
\hline
\end{tabular}

from the cancerous tissues from the anterior and deep region to ensure tumour adequacy and only the part of the cancerous tissue that had greater than $90 \%$ malignant cells was used in this study. Tissues were stored at $-80^{\circ} \mathrm{C}$ prior to analysis.

2.3. Protein Extraction. Frozen tissues were thawed at room temperature $\left(25^{\circ} \mathrm{C}\right)$, rinsed with distilled water and homogenized on ice for $5 \mathrm{~min}$. Proteins were extracted by addition of Tris buffer (TRIS) ((40 mM Tris, $1 \mathrm{mM} 4$-(2-Aminoethyl) benzenesulfonyl fluoride (AEBSF)) to the homogenized tissue. After centrifugation $\left(13000 \mathrm{rpm}, 20 \mathrm{~min}, 20^{\circ} \mathrm{C}\right)$, the supernatant was collected and the protein concentration was determined in duplicates by RC-DC protein assay (Bio-Rad, USA).

2.4. Protein Preparation. Prior to isoelectric focusing, TRIS protein extracts were first precipitated by using trichloroacetic acid (TCA)/acetone method [22]. Ten percent TCA in ice-cold acetone containing $20 \mathrm{mM}$ dithiothreitol (DTT) was added to the TRIS extracts and incubated at $-20^{\circ} \mathrm{C}$ for $1.5 \mathrm{~h}$. After centrifugation $\left(13000 \mathrm{rpm}, 15 \mathrm{~min}, 4^{\circ} \mathrm{C}\right)$, the pellet was washed with ice-cold acetone containing $20 \mathrm{mM}$ DTT before being centrifuged $\left(13000 \mathrm{rpm}, 15 \mathrm{~min}, 4^{\circ} \mathrm{C}\right)$. The supernatant was discarded and the pellet was resolubilized in thiourea lysis buffer (TLB) (8 M Urea, $2 \mathrm{M}$ Thiourea, 4\% (w/v) 3-[(3Cholamidopropyl)dimethylammonio]-1-propanesulfonate

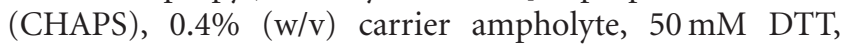
$1 \mathrm{mM}$ AEBSF) and incubated for $1 \mathrm{~h}$ at $25^{\circ} \mathrm{C}$.

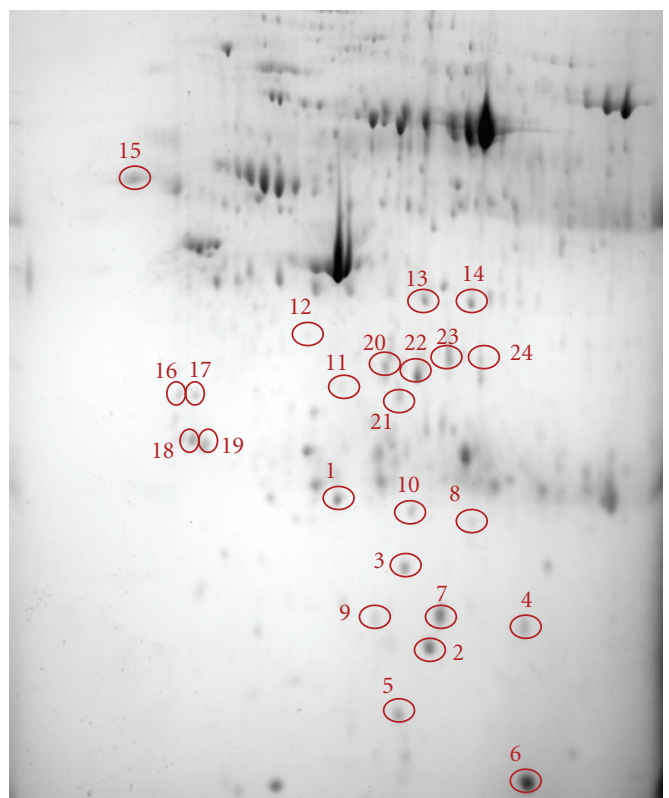

Figure 2: Protein spots selected for in-gel digestion.

2.5. 2D-Gel Electrophoresis. A protein extract containing $250 \mathrm{mg}$ protein was passively rehydrated unto an $11 \mathrm{~cm} \mathrm{pH}$ 4-7 IPG strips (Bio-Rad, USA) for $15 \mathrm{~h}$ at $20^{\circ} \mathrm{C}$. Isoelectric focusing (IEF) was performed using the Protean IEF Cell (Bio-Rad, USA) at $20^{\circ} \mathrm{C}$ for $15 \mathrm{~min}$ at $250 \mathrm{~V}, 2.5 \mathrm{~h}$ at $8000 \mathrm{~V}$ and held at $8000 \mathrm{~V}$ for $30 \mathrm{kVh}$. The proteins were equilibrated by adding in equilibration buffer I ( $6 \mathrm{M}$ Urea, 
TABLE 2: Identity and properties of twenty-four differentially expressed proteins.

\begin{tabular}{|c|c|c|c|c|c|c|c|c|}
\hline $\begin{array}{l}\text { Protein spot } \\
\text { no. }\end{array}$ & $\begin{array}{l}\text { SwissProt } \\
\text { Accession } \\
\text { Number } \\
\end{array}$ & Protein name & Molecular class & $\begin{array}{c}\text { Molecular } \\
\text { weight (Da) }\end{array}$ & $\begin{array}{l}\text { Isoelectric } \\
\text { point (pI) }\end{array}$ & $\begin{array}{l}\text { GRAVY } \\
\text { score }\end{array}$ & $\begin{array}{l}\text { MOWSE } \\
\text { score }\end{array}$ & $\begin{array}{c}\text { Sequence } \\
\text { coverage }(\%)\end{array}$ \\
\hline 1 & P02768 & $\begin{array}{l}\text { Serum albumin } \\
\text { precursor }\end{array}$ & Transport/cargo & 71397 & 5.92 & -0.354 & 96 & 14 \\
\hline 2 & P00441 & $\begin{array}{l}\text { Superoxide } \\
\text { dismutase }\end{array}$ & Oxidoreductase & 16168 & 5.70 & -0.344 & 52 & 9 \\
\hline 3 & P32119 & Peroxiredoxin-2 & Oxidoreductase & 21935 & 5.67 & -0.199 & 260 & 26 \\
\hline 4 & P00739 & $\begin{array}{l}\text { Haptoglobin- } \\
\text { related } \\
\text { precursor }\end{array}$ & Transport/cargo & 39529 & 6.42 & -0.308 & 43 & 3 \\
\hline 5 & P02766 & $\begin{array}{l}\text { Transthyretin } \\
\text { precursor }\end{array}$ & Transport/cargo & 16003 & 5.52 & -0.029 & 75 & 22 \\
\hline 6 & P15090 & $\begin{array}{l}\text { Fatty acid binding } \\
\text { protein }\end{array}$ & Carrier protein & 14704 & 6.81 & -0.249 & 223 & 24 \\
\hline 7 & P00738 & $\begin{array}{l}\text { Haptoglobin } \\
\text { precursor, allele } 2 \\
\text { (validated) }\end{array}$ & Transport/cargo & 45901 & 6.13 & -0.421 & 56 & 6 \\
\hline 8 & P02768 & $\begin{array}{l}\text { Serum albumin } \\
\text { precursor } \\
\text { (validated) }\end{array}$ & Transport/cargo & 69366 & 5.92 & -0.354 & 46 & 4 \\
\hline 9 & P00739 & $\begin{array}{l}\text { Haptoglobin- } \\
\text { related protein } \\
\text { precursor }\end{array}$ & Transport/cargo & 39529 & 6.42 & -0.308 & 55 & 3 \\
\hline 10 & P09211 & $\begin{array}{l}\text { Glutathione } \\
\text { transferase }\end{array}$ & Transferase & 23464 & 5.42 & -0.121 & 277 & 53 \\
\hline 11 & P68371 & $\begin{array}{l}\text { Class IV beta } \\
\text { tubulin }\end{array}$ & $\begin{array}{l}\text { Structural } \\
\text { protein }\end{array}$ & 50217 & 4.82 & -0.362 & 52 & 13 \\
\hline 12 & P55735 & $\begin{array}{l}\text { SEC13-like 1, } \\
\text { isoform b }\end{array}$ & Transport/cargo & 36062 & 5.22 & -0.372 & 115 & 37 \\
\hline 13 & P02675 & $\begin{array}{l}\text { Fibrinogen beta } \\
\text { chain precursor }\end{array}$ & $\begin{array}{l}\text { Coagulation } \\
\text { factor }\end{array}$ & 56624 & 8.54 & -0.758 & 87 & 28 \\
\hline 14 & P02675 & $\begin{array}{l}\text { Fibrinogen beta } \\
\text { chain precursor }\end{array}$ & $\begin{array}{l}\text { Coagulation } \\
\text { factor }\end{array}$ & 56624 & 8.54 & -0.758 & 134 & 31 \\
\hline 15 & P27797 & Calreticulin & $\begin{array}{c}\text { Calcium } \\
\text { binding protein }\end{array}$ & 47092 & 4.30 & -1.104 & 107 & 29 \\
\hline 16 & Not available & $\begin{array}{l}\text { Unidentified } \\
\text { protein }\end{array}$ & N/A & $\mathrm{N} / \mathrm{A}^{*}$ & N/A & N/A & N/A & N/A \\
\hline 17 & Q63610 & $\begin{array}{l}\text { Hypothetical } \\
\text { protein }\end{array}$ & $\begin{array}{l}\text { Hypothetical } \\
\text { protein }\end{array}$ & 27407 & 4.71 & -0.992 & 59 & 27 \\
\hline 18 & P63104 & $\begin{array}{l}\text { 14-3-3 protein zeta } \\
\text { (kinase regulator) }\end{array}$ & $\begin{array}{l}\text { Adaptor } \\
\text { molecule }\end{array}$ & 27745 & 4.73 & -0.621 & 193 & 47 \\
\hline 19 & Q04917 & $14-3-3$ protein eta & $\begin{array}{l}\text { Adaptor } \\
\text { molecule }\end{array}$ & 28244 & 4.76 & -0.618 & 71 & 23 \\
\hline 20 & P52907 & $\begin{array}{l}\text { F-actin capping } \\
\text { protein }\end{array}$ & $\begin{array}{l}\text { Cytoskeletal } \\
\text { protein }\end{array}$ & 32965 & 5.45 & -0.668 & 53 & 26 \\
\hline 21 & P02766 & $\begin{array}{l}\text { Transthyretin } \\
\text { precursor }\end{array}$ & Transport/cargo & 16003 & 5.52 & -0.029 & 85 & 22 \\
\hline 22 & P68133 & Actin alpha & $\begin{array}{l}\text { Cytoskeletal } \\
\text { protein }\end{array}$ & 38172 & 5.39 & -0.161 & 64 & 17 \\
\hline 23 & P07195 & $\begin{array}{l}\text { L-lactate } \\
\text { dehydrogenase }\end{array}$ & Dehydrogenase & 36928 & 5.71 & 0.056 & 222 & 34 \\
\hline 24 & P21695 & $\begin{array}{l}\text { Glycerol-3- } \\
\text { phosphate } \\
\text { dehydrogenase }\end{array}$ & Dehydrogenase & 38206 & 5.81 & 0.106 & 312 & 51 \\
\hline
\end{tabular}




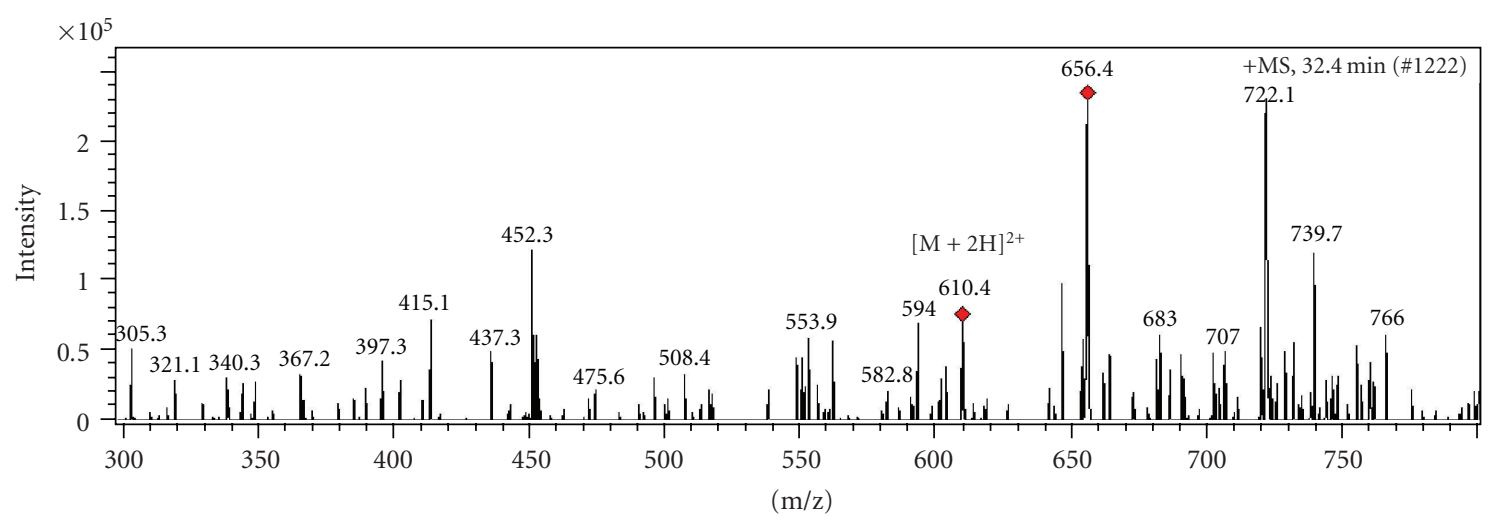

(a)

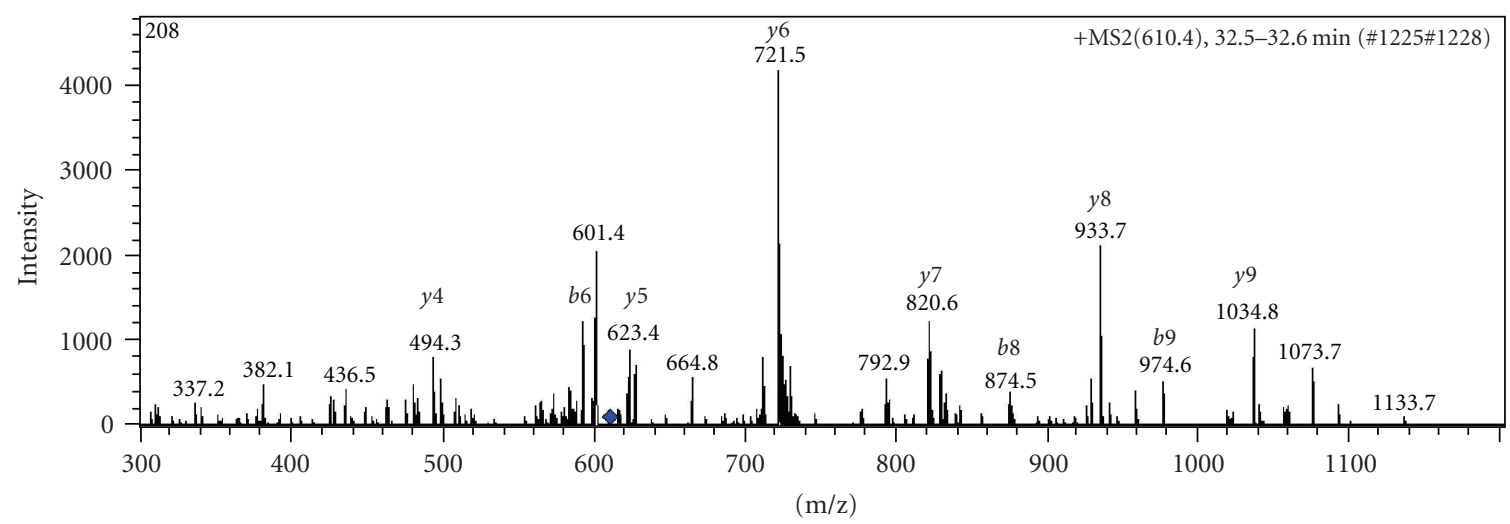

(b)

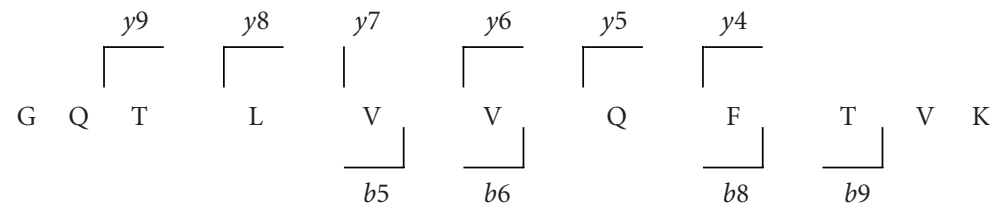

(c)

FIGURE 3: Identification of protein. (a) Full scan MS spectrum of peptide eluted out at 32.4 minutes. (b) MS/MS spectrum of 610.4 product ions. (c) Amino acid sequence of peptide eluted out 32.4 minutes.

0.375 M Tris- $\mathrm{HCl}, \mathrm{pH} 8.8,2 \%$ SDS, 20\% glycerol, $1 \%$ $(\mathrm{w} / \mathrm{v})$ DTT) to the focused IPG strip for $10 \mathrm{~min}$ at $25^{\circ} \mathrm{C}$, followed by the addition of equilibration buffer II ( $6 \mathrm{M}$ Urea, $0.375 \mathrm{M}$ Tris- $\mathrm{HCl}, \mathrm{pH} 8.8,2 \%$ SDS, 20\% glycerol, $2.5 \%$ $(\mathrm{w} / \mathrm{v})$ iodoacetamide) for $10 \mathrm{~min}$ at $25^{\circ} \mathrm{C}$. The IPG strip was positioned on top of a $10 \%$ sodium dodecyl sulfatepolyacrylamide gel (SDS-PAGE) $(135 \times 160 \times 1 \mathrm{~mm})$ and electrophorised in a PROTEAN II xi Cell (Bio-Rad, USA) at a constant voltage of $200 \mathrm{~V}$ for 3 hours according to the method of Laemmli [23]. After electrophoresis, the gels were stained using Coomassie Brilliant Blue 250 (CBR$250)$ solution (0.1\% (w/v) CBR-250, 40\% (v/v) methanol, $10 \%(\mathrm{v} / \mathrm{v})$ acetic acid) for $4 \mathrm{~h}$. The staining background was removed by incubating the gel in a destaining solution $(40 \%(\mathrm{v} / \mathrm{v})$ methanol, $2 \%(\mathrm{v} / \mathrm{v})$ acetic acid) twice for $2 \mathrm{~h}$ each.
2.6. Gel Imaging and Analysis. The images of 2D-PAGE gels were captured by using Versadoc system (Bio-Rad, USA). The gel images were processed and analyzed by using PDQuest software 7.3 (Bio-Rad, USA). The software created a match set to compare the images of cancerous and normal breast tissues, which was then used to analyze quantitative and qualitative differences in protein spots between the images. Each protein spot was normalized by dividing the spot intensity with the total intensity value of all the pixels in the gel image in order to quantitate the spot and to correct slight variations in protein loading. A protein was considered as up-regulated if its expression level in cancerous tissues was increased 1.5-fold or more as compared to normal breast tissue: it was considered as down-regulated if its expression level in cancerous tissues was decreased 1.5fold or more as compared to the normal breast tissue. The 

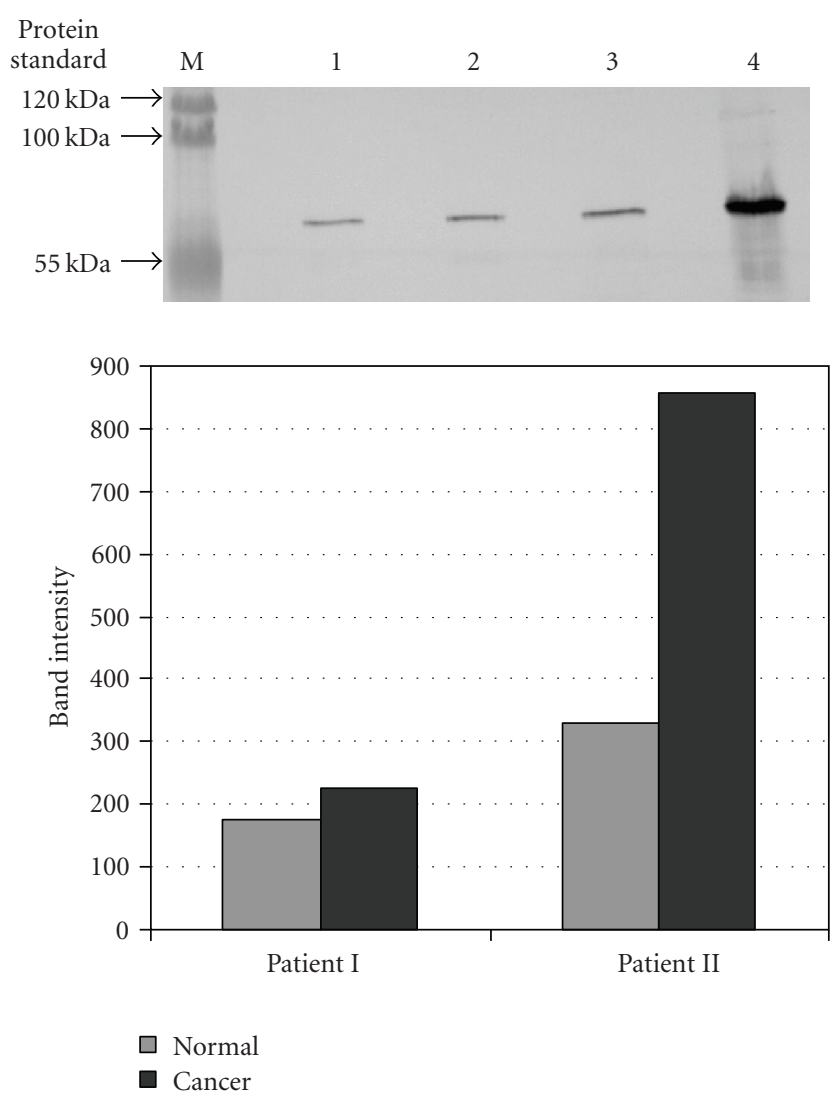

Figure 4: Immunoblot of annexin V. Lane M: protein molecular weight markers (in $\mathrm{kDa}$ ). Lane 1: normal TRIS extract from first patient. Lane 2: cancer TRIS extract from first patient. Lane 3: normal TRIS extract from second patient. Lane 4: cancer TRIS extract from second patient.

statistical significance of the protein's differential expression was determined by using the Wilcoxon signed-rank test available in the PDQuest software.

\subsection{In Gel Digestion and Liquid Chromatography Tandem} Mass Spectrometry (LC/MS/MS) Analysis. In gel digestion was performed according to Othman et al. [24]. Briefly, protein spots of interest were excised from the gel. They were washed with deionized water, cut in fine pieces, hydrated and dehydrated with $100 \mathrm{mM}$ ammonium bicarbonate $\left(\mathrm{NH}_{4} \mathrm{HCO}_{3}\right)$ and acetonitrile $(\mathrm{ACN})$, respectively, in order to remove the stain material. The protein was reduced in situ with DTT and alkylated with iodoacetamide and finally digested into peptides by treating it with trypsin. The tryptic peptides were eluted from the gel and dried under the continuous flow of nitrogen gas. Peptides were reconstituted in $30 \mu \mathrm{L}$ of $0.1 \%(\mathrm{v} / \mathrm{v})$ formic acid in a solution of deionized water:acetonitrile $(85: 15)$ and were fractionated by RPHPLC $(\mathrm{C} 18,150 \times 0.3 \mathrm{~mm}, 5 \mu \mathrm{m} 300 \AA)$ using an Agilent 1100 Series. The mobile phases A $(0.1 \%$ formic acid in deionized water) and $\mathrm{B}(0.1 \%$ formic acid in $\mathrm{ACN})$ are pumped at a constant flow rate of $4 \mu \mathrm{L} / \mathrm{min}$. The peptides were eluted by a linear gradient of $5 \%$ B to $95 \%$ B in
70 min and held constant at 95\% B for 5 min. The HPLC was interfaced to an ESI-ion trap mass analyzer (Agilent). Two types of scan were performed: full scan MS and full scan MS/MS, where the two most intense ions in an MS scan that exceeded the set threshold of 5000 counts will be isolated for MS/MS scan to produce a series of product ions spectrum for protein identification. The instrumental parameters used were Nebulizer pressure at $20.0 \mathrm{psi}$, auxiliary dry gas flow of $6.0 \mathrm{~L} / \mathrm{min}$, auxiliary dry gas temperature at $300^{\circ} \mathrm{C}$, capillary voltage at $3.5 \mathrm{kV}$, exit capillary voltage $84.5 \mathrm{~V}$, skimmer 1 voltage at $17.2 \mathrm{~V}$, skimmer 2 voltage at $6.0 \mathrm{~V}$. MS scan region from $200-1800 \mathrm{~m} / \mathrm{z}$ with a scan time $1 \mathrm{~s}$ and a interscan time of $0.1 \mathrm{~s}$. The MS/MS scan parameters were Default collision energy (voltage) of $1.15 \mathrm{~V}$, charge state of 2 , minimum threshold of 5000 counts, and isolation width of $2 \mathrm{~m} / \mathrm{z}$. Protein identification was done by submitting the MS/MS data to a MASCOT database search engine at http://www.matrixscience.com/. The search parameters used were Homo sapiens for taxonomy, carboxymethyl for fixed modifications, peptide tolerance of $\pm 2 \mathrm{Da}$, MS/MS tolerance of $\pm 0.8 \mathrm{Da}$, and average experimental mass value.

2.8. Western Blotting. Western blotting was carried out using a semidry method according to Lauriere [25]. Protein extracts were separated by one-dimensional SDS-PAGE according to Laemmli [23]. The gel was incubated in a cold transfer buffer $(25 \mathrm{mM}$ Tris, $192 \mathrm{mM}$ Glycine and $1.3 \mathrm{mM}$ SDS, $\mathrm{pH} 8.3$ ) for $30 \mathrm{~min}$. The proteins were transferred from the gel to a nitrocellulose membrane (Bio-Rad, USA) in a TE 70 Semiphor semidry transfer unit (Hoefer Scientific, Germany) at $134 \mathrm{~mA}$ for $1.5 \mathrm{~h}$. The membrane was incubated with blocking buffer (3\% (w/v) bovine serum albumin (BSA) in phosphate buffered saline (PBS)) for $2 \mathrm{~h}$ at $25^{\circ} \mathrm{C}$. After washing with PBS, the membrane was incubated in $20 \mathrm{~mL}$ of mouse antiannexin $\mathrm{V}$ antibody (Abnova, Taiwan) with a $1: 2000$ dilution in antibody diluent buffer $(0.1 \%$ (w/v) BSA, $0.1 \%$ Tween $20,0.02 \%$ sodium azide in PBS) overnight at $25^{\circ} \mathrm{C}$. After PBS washing, the membrane was incubated in $50 \mathrm{~mL}$ of horseradish peroxidase (HRP) conjugated anti-mouse secondary antibody (Bio-Rad, USA) at $1: 3000$ dilution for $2 \mathrm{~h}$ at $25^{\circ} \mathrm{C}$. After being washed with PBS, $20 \mathrm{~mL}$ of 4-Chloro naphthol (4CN), substrate solution (Bio-Rad, USA) was added to the membrane until the band is visualized.

\section{Results}

In this study, similar amount of protein and identical separation and staining conditions were applied to all the samples. Although the pattern of the 2D images for cancerous and normal breast tissues was relatively similar, the intensities of the spots varied between the tissues types. Figure 1 shows examples of 2D images of cancerous and normal tissues obtained from the same patient. The difference in spots intensities indicates the differentially expressed proteins between the cancerous and normal tissues, these spots were excised and subjected to mass spectrometry analysis for protein identification. These spots are shown in Figure 2. 


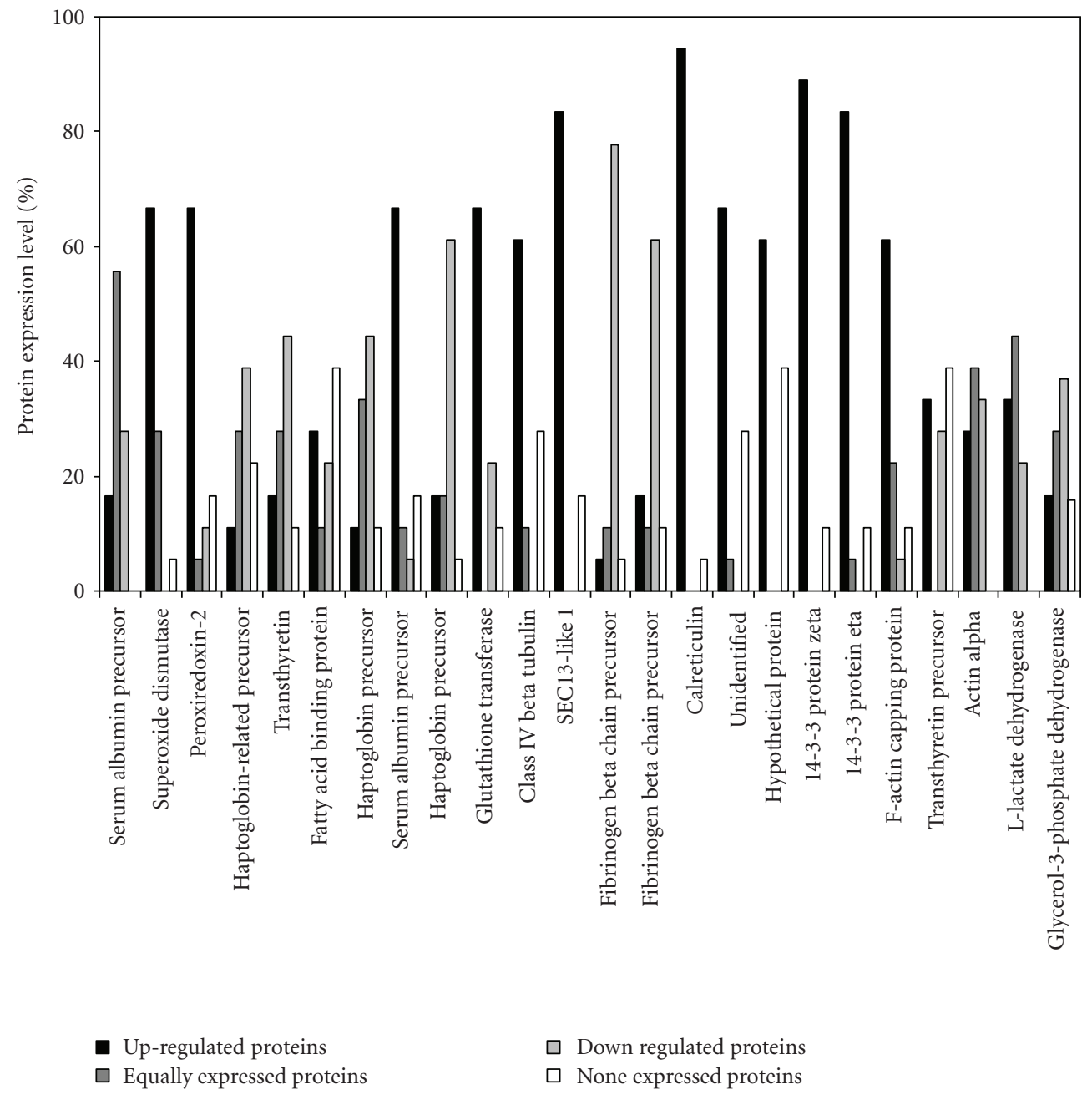

FIGURE 5: Distribution of proteins in TRIS extracts of all patients. The expression of proteins was defined as upregulation, downregulation, equal expression, and nonexpression in each patient.

A total of 24 differentially expressed protein spots were subjected to further analysis and the protein identities were listed in Table 2. The grand average of hydropathy (GRAVY) scores indicate the polarity of the proteins, the more negative the score represents the higher hydrophilicity of the protein. Figure 3 shows the MS and MS/MS spectra of one of the proteins. After being subjected to MASCOT protein database search, the peptide was found to belong to annexin $\mathrm{V}$; the identity of the protein was further confirmed by western blotting experiment shown in Figure 4 . Out of the 24 proteins, four proteins were up-regulated while one protein was down-regulated in $>75 \%$ of patients tested. The up-regulated proteins was SEC13-like 1 (isoform b), calreticulin, 14-3-3 protein zeta and 14-3-3 protein eta. The down-regulated protein was fibrinogen beta chain precursor. The Wilcoxon signed-rank test was used to determine the statistical significance of the changes in protein expression levels between the two tissues types. The differential expression of these proteins were statistically significant with a 95\% confidence level $(P<.05)$. The expression levels of the rest of the proteins identified were inconsistent between patients, where their expression levels range from $6 \%$ to $67 \%$ variation. We did not detect any unique protein from cancerous or normal tissues. Figure 5 shows the expression levels of the 24 proteins in all the patients; the expression levels were categorized as upregulation, equal expression, downregulation or nonexpression in the patients tested.

Nine up-regulated proteins and one down-regulated proteins were detected at a significant level $(P<.05)$ in $>70 \%$ of the Stage II patients $(n=7)$. The proteins that up-regulated were superoxide dismutase, peroxiredoxin-2, serum albumin precursor, class IV beta tubulin, SEC13-like 1 (isoform b), calreticulin, unidentified protein, 14-3-3 protein zeta and 14-3-3 protein eta while fibrinogen beta chain precursor was significantly down-regulated. Haptoglobin precursor which was down-regulated in $>70 \%$ stage II patients was not statistically significant. In contrary, Hypothetical protein (protein spot 16) was down-regulated in $<70 \%$ of Stage II patients, but the change in its expression level was statistically significant. Figure 6 shows the percentage of upregulation, equal expression, downregulation and nonexpression of the proteins in Stage II patients. 


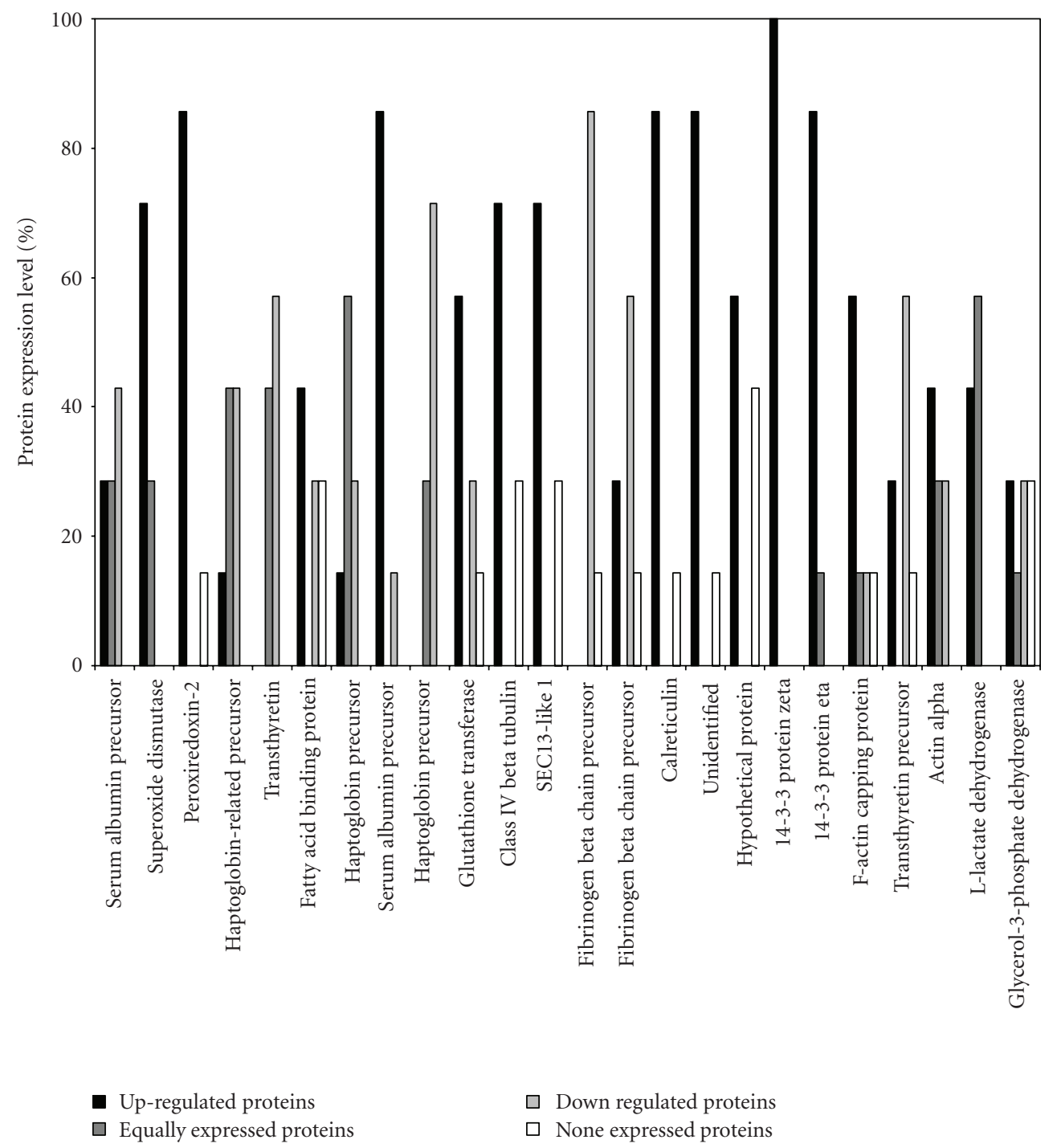

FIgURE 6: Distribution of proteins in Stage II patients.

Four proteins were up-regulated and one protein was down-regulated significantly $(P>.05)$ in $>70 \%$ of the Stage III patients $(n=10)$ tested. These up-regulated proteins were SEC13-like 1 (isoform b), calreticulin, 14-3-3 protein zeta and 14-3-3 protein eta, while the down-regulated protein was fibrinogen beta chain precursor. Glutathione transferase was up-regulated in $>70 \%$ of Stage III patients but the change in its expression level was not statistically significant. On the other hand, superoxide dismutase, serum albumin precursor, class IV beta tubulin, and F-actin capping protein were up-regulated in $<70 \%$ of Stage III patients, however, their upregulations were statistically significantly in Stage III patients. Haptoglobin precursor was significantly down-regulated in $<70 \%$ of Stage III patients. Figure 7 shows the percentage of upregulation, equal expression, downregulation and nonexpression of the proteins for Stage III patients.

Five proteins were significantly $(P<.05)$ up-regulated in $>70 \%$ of the Grade II patients $(n=7)$. These proteins were superoxide dismutase, class IV beta tubulin, SEC-like 1 (isoform b), calreticulin and $\mathrm{F}$-actin capping protein. Glutathione transferase, 14-3-3 protein zeta, and 14-3-3 protein eta were up-regulated in $>70 \%$ of Grade II patients but their upregulation was not statistically significant. On contrary, peroxiredoxin-2 was significantly up-regulated in $<70 \%$ of Grade II patients. Figure 8 shows the percentage of upregulation, equal expression, downregulation and nonexpression of the proteins in Grade II patients.

Seven up-regulated proteins and one down-regulated proteins were significantly expressed in $>70 \%$ of Grade III patients $(n=9)$. The up-regulated proteins were peroxiredoxin-2, SEC-like 1 (isoform b), calreticulin, unidentified protein, hypothetical protein, 14-3-3 protein zeta and 14-3-3 protein eta while the down-regulated protein was fibrinogen beta chain precursor. Additionally, superoxide dismutase, serum albumin precursor and class IV beta tubulin were significantly up-regulated while haptoglobin precursor was significantly down-regulated in $<70 \%$ of 


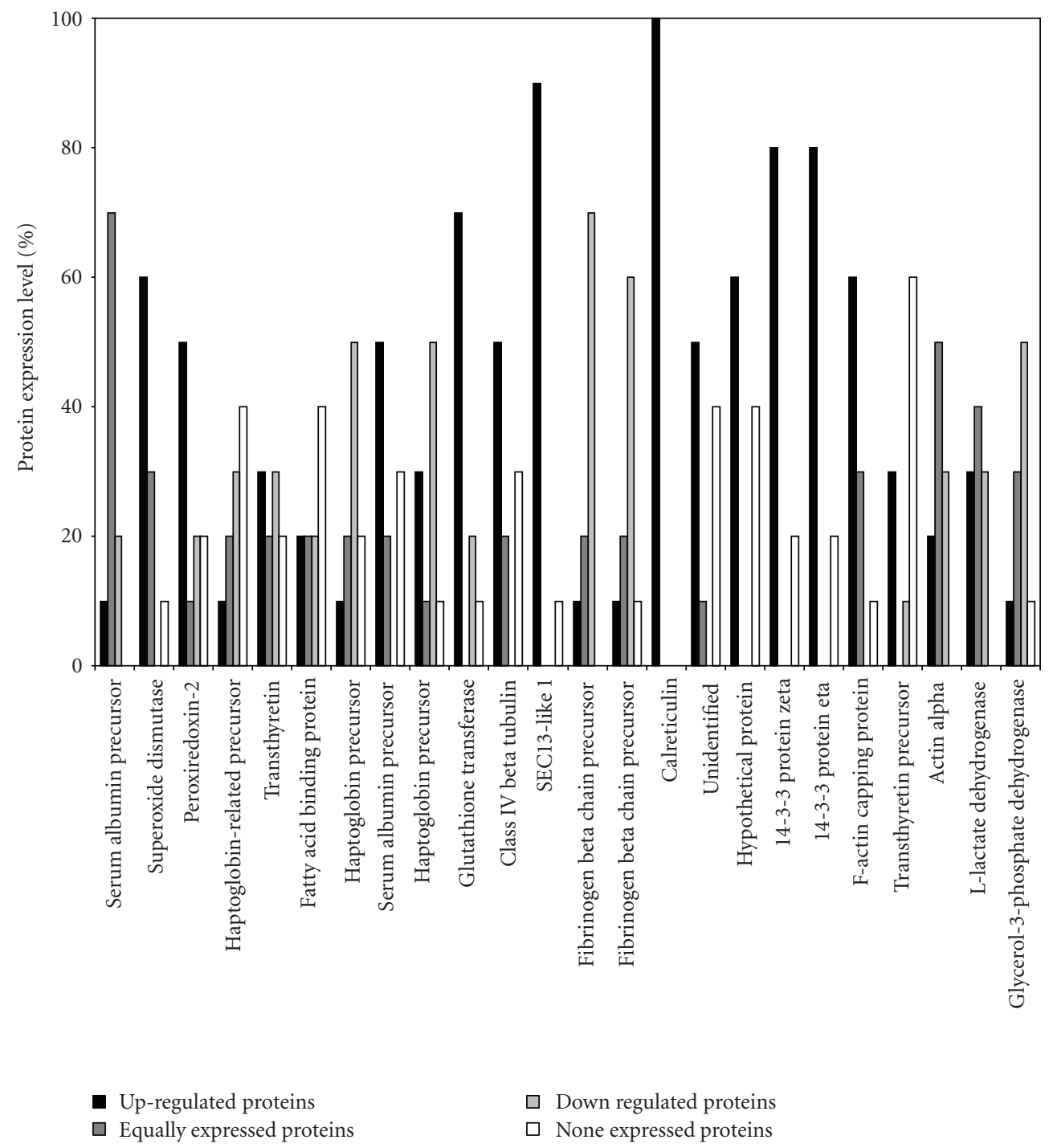

FIgURE 7: Distribution of proteins in Stage III patients.

Grade III patients. Figure 9 shows the percentage of upregulation, equal expression, downregulation and nonexpression of the proteins in Grade III patients.

There were 12 proteins that were up-regulated significantly in at least one of the stage and grade. Figure 10 shows the upregulation of these proteins in stage II, stage III, grade II, and grade III patients. Superoxide dismutase was up-regulated at $71 \%$ in stage II and grade II patients and at $60 \%$ in stage III and grade III patients. Peroxiredoxin2 was up-regulated at $86 \%$ in stage II patients and at $50 \%$, $57 \%$ and $50 \%$ in stage III, grade II and grade III patients, respectively. Serum albumin precursor was up-regulated at $86 \%$ in stage II patients and at $50 \%, 57 \%$ and $67 \%$ in stage III, grade II and grade III patients, respectively. Glutathione transferase was up-regulated at $70 \%$ and $71 \%$ in stage III and grade II patients, respectively. Its upregulation in stage II and grade III patients were $57 \%$ and $67 \%$, respectively. Class IV beta-tubulin was up-regulated at $71 \%$ in both stage II and grade II patients and at $50 \%$ and $67 \%$ in stage III and grade III patients, respectively. SEC13-like 1 was upregulated at $71 \%, 90 \%, 86 \%$ and $78 \%$ in stage II, III, grade II and III patients, respectively. Calreticulin was up-regulated at $86 \%, 100 \%, 100 \%$ and $89 \%$ in stage II, III, grade II and III patients, respectively. The unidentified protein (protein spot 16) was up-regulated at $86 \%$ and $78 \%$ of stage II and grade III patients, respectively and at $50 \%$ and $57 \%$ in stage III and grade II patients, respectively. Hypothetical protein was up-regulated at $78 \%$ in grade III patients and at $57 \%, 60 \%$ and $43 \%$ in stage II, III and grade II patients, respectively. $14-3-3$ protein zeta was up-regulated in all stage and grade groups at $100 \%, 80 \%, 71 \%$ and $100 \%$ in stage II, III, grade II and III patients, respectively. 14-33 protein eta was up-regulated in $85 \%, 80 \%$ and $100 \%$ of stage II, III and grade III patients, respectively. However, its upregulation in grade II patients was only $57 \%$. F-actin capping protein was up-regulated at $85 \%$ in grade II patients and at $57 \%, 60 \%$ and $56 \%$ in stage II, III and grade III patients, respectively. 


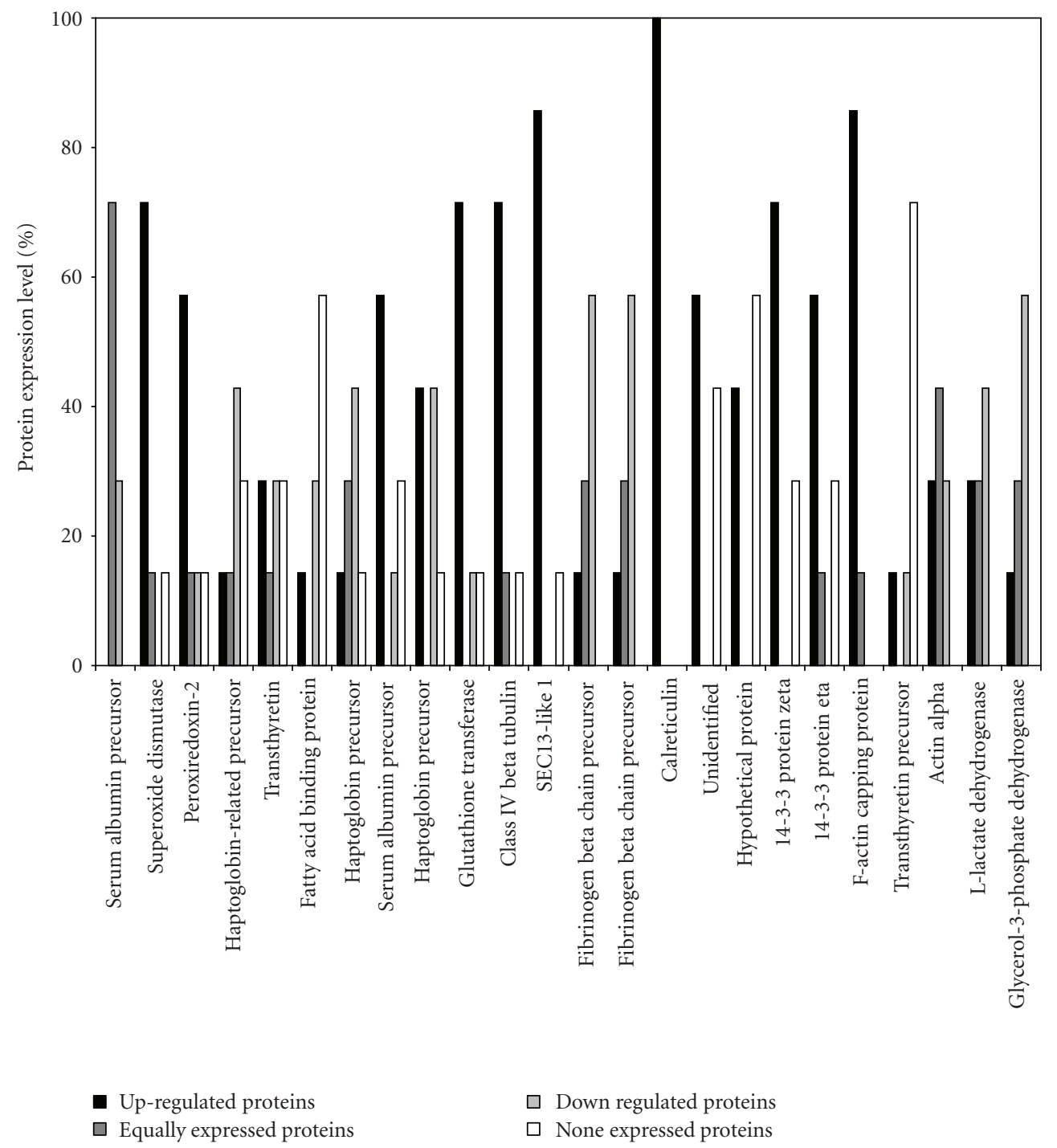

FIGURE 8: Distribution of proteins in Grade II patients.

\section{Discussion}

Tissues heterogeneity is the main problem encountered when conducting proteomic analysis on tissue specimens. In this study, only the part of cancerous tissues with $>90 \%$ malignancy was used to ensure tumour adequacy. We used the normal tissue adjacent to the tumour tissue for comparison purpose, we found that this is crucial due to tissue heterogeneity between patients, although there was a consistent protein profiles obtained from the patients, the profiles were not identical. This can be explained as proteins are expression components of cells, and therefore they will be expressed differently under different environment which caused as variations between tissues from different patients; therefore, the best comparison for protein expression would be between the cancerous and normal tissues from the same patients. Despite this, the drawback of using such normal tissues as the control is that these tissues may possess some molecular and epigenetic abnormalities. We overcome this problem by only collecting the normal tissues that were confirmed normal by pathologist; a minute contamination that derived from tissue abnormalities would be excluded as the minute proteins derived from the abnormal tissues would not be detected under Commassie blue staining. In addition, we focused only on the proteins that showed consistent expression in the patients in order to minimize false identification of protein that resulted from tissue heterogeneity between patients or sample handling (Seng et al. [26]). Furthermore, normalization of the gel intensity was carried out prior to the determination of the target protein spots intensities, where the intensity of each protein spot was calculated as the percentage to the total intensity of all the spots on the same image. This approach was taken to reduce the variation in protein spot intensity that may be caused by variability in sample loading. The main limitation of this study is the number of tissues used, nevertheless, potential 


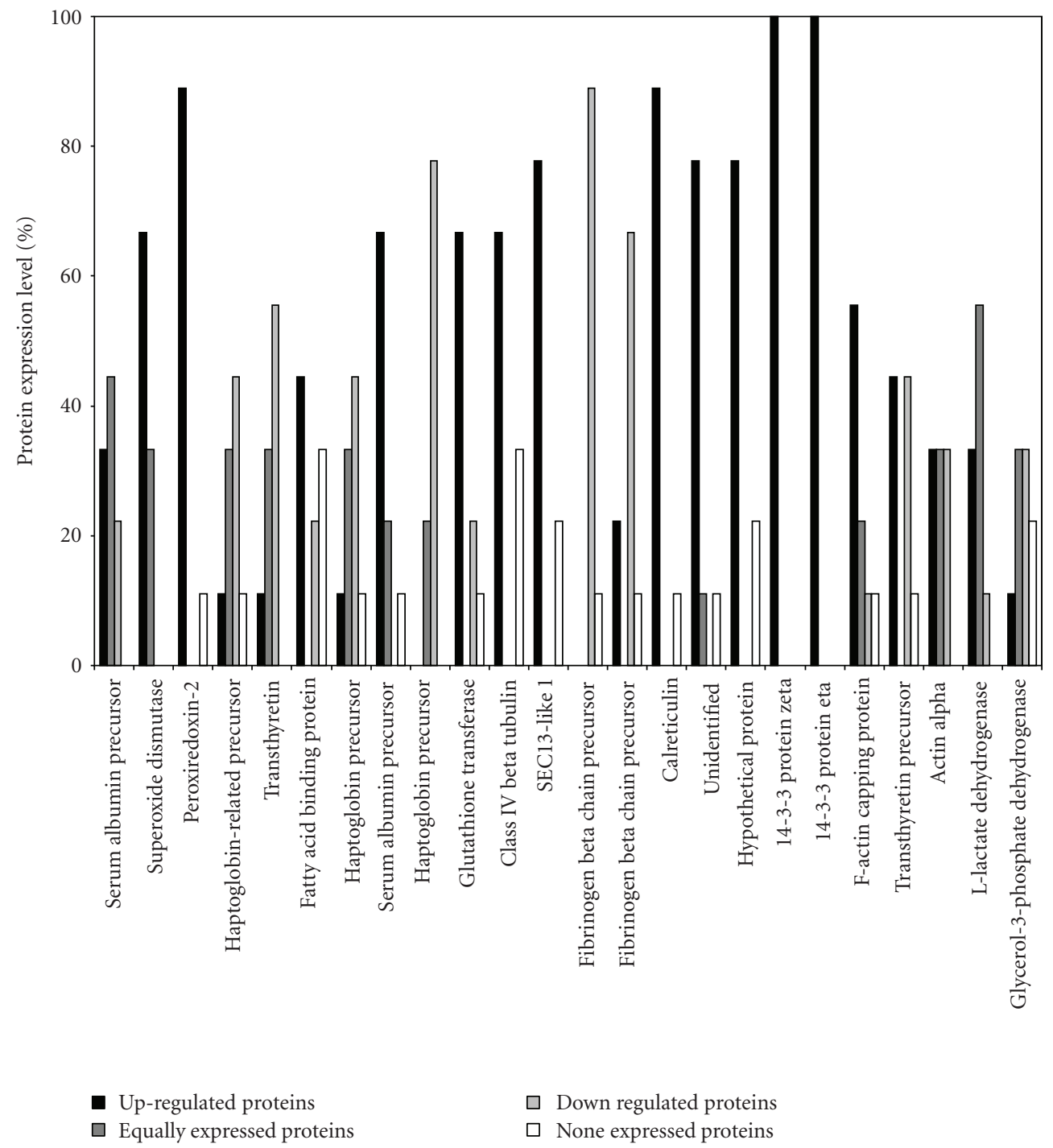

FIGURE 9: Distribution of proteins in Grade III patients.

biomarkers with consistent and significant upregulation in patients were identified that worth further investigation with a greater number of tissues.

Since proteins are the functional components of cells that regulate cell's activity, it would be interesting to relate the expression of the differentially expressed proteins with the various stages and grades of tumour. We have identified a few proteins that can be strongly and significantly related with certain stages and grades of IDC. 14-3-3 protein zeta was found up-regulated significantly $(P<.05)$ in all $(100 \%)$ the patients with grade III cancer and also in all the patients with stage II cancer while 14-3-3 protein eta was detected upregulated significantly in all $(100 \%)$ the grade III patients tested. Calreticulin was found to be a good biomarker for all the grades and stages tested in this study, where its expression levels were $100 \%$ in grade II patients and also stage III patients, respectively, and as for grade III patients and stage II patients, its expression levels were greater than $80 \%$ in both the two cohorts. Other proteins with $>80 \%$ expression levels in grade II patients were F-actin capping protein and SEC13-like 1 protein. In stage III patients, 14-3-3 protein eta, 14-3-3 protein zeta and SEC13-like 1 were expressed at $\geq 80 \%$. 14-3-3 protein eta, an unidentified protein $(60 \mathrm{kDa})$, calreticulin, serum albumin precursor and peroxiredoxin-2 were expressed at $>80 \%$ in stage II patients. In general, we have identified four proteins that can be strongly and significantly related to at least one of the stages or grades tested in this study, these proteins were SEC13-like 1, calreticulin, 14-3-3 protein zeta and 14-3-3 protein eta.

There was an interesting trend of expressions shown by these four proteins, whereby both the 14-3-3 protein eta and zeta were shown to be strongly related with grade III patients and stage II patients indicating that the proteins may be associated with the aggressiveness of the tumour before the tumour spread. On the other hand, calreticulin and SEC13like 1 were related more strongly with grade II patients and stage III patients indicating that as the tumour has spread to lymph nodes, the expression of these proteins increases. 


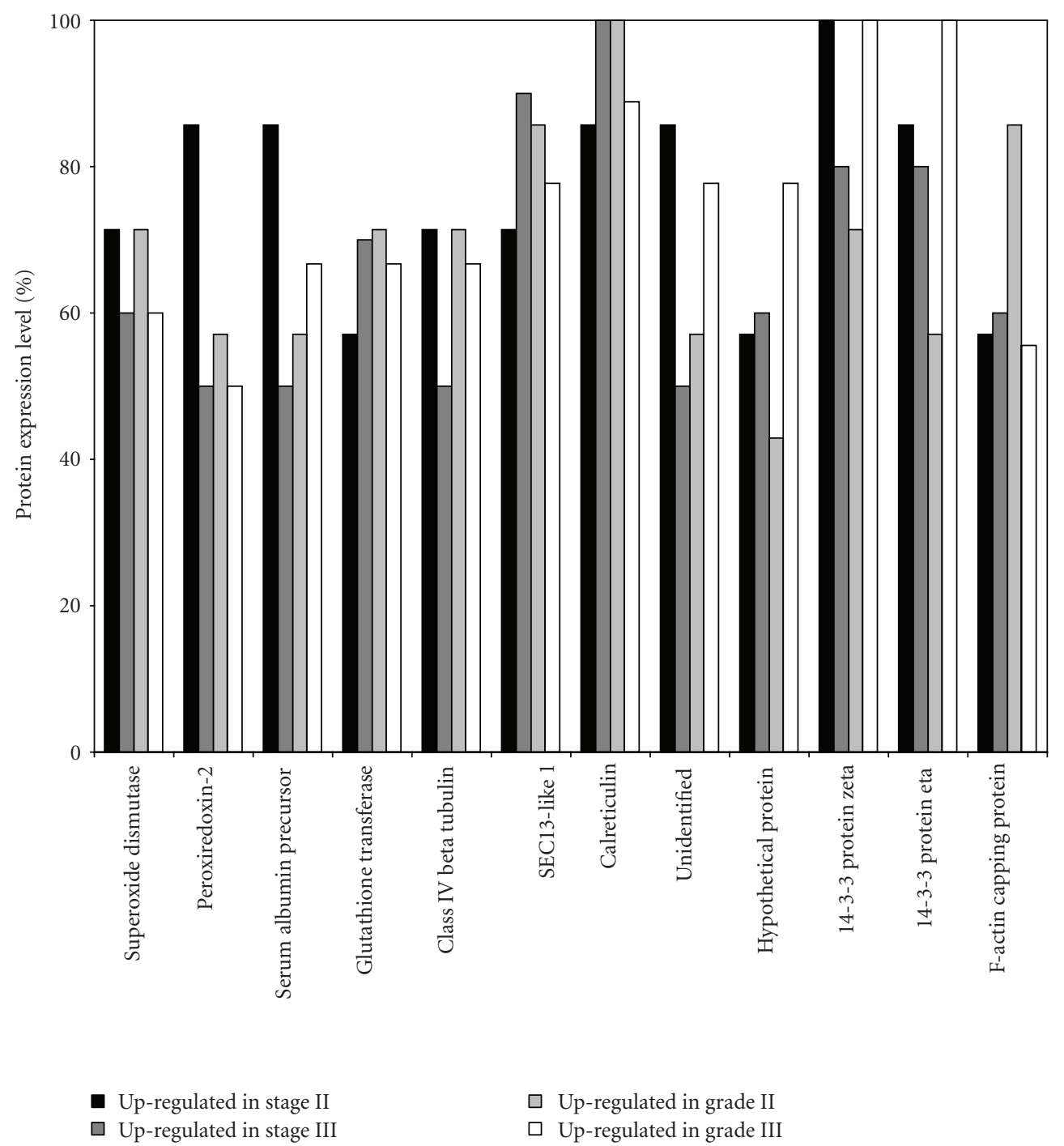

Figure 10: Comparison of up-regulated proteins in Stage II, Stage III, Grade II and Grade III patients.

Besides stage and grade, the expression levels of a few receptors such as progesterone, estrogen and C-ERB- $\mathrm{B}_{2}$ and the combinations of the three receptors as triple positive and triple negative grading were also used in the prediction of the prognosis of the disease. In this study, we found that within the stages and grades tested, the expressions of the four proteins were not correlated with the expressions of these receptors (see supplementary material available online at doi: 10.1155/2010/516469).

Calreticulin is a $48 \mathrm{kDa}$ multifunctional calcium ionbinding protein that regulates cellular activities in the endoplasmic reticulum (ER) [27]. It binds to misfolded proteins to prevent them from being transported to the Golgi apparatus. Calreticulin has been reported to be highly expressed in human breast ductal carcinoma cells compared to normal breast cells [28-30].

14-3-3 eta protein (YWAH) and 14-3-3 zeta protein (YWAZ) are subunits of the 14-3-3 isoform proteins (14$3-3)$. These proteins bind to proteins which are involved in the signaling pathway, including kinases and transmembrane receptors. 14-3-3 interact with signaling proteins to regulate a wide variety of cellular events [31-35]. 14-3-3 regulate cancer-related processes, where they inhibit apoptosis, act as cell cycle checkpoints $[36,37]$ and control oncogene products that are overexpressed in cancer cells [38]. 14-3-3 were up-regulated in breast ductal carcinoma tumour cells [39].

Protein SEC13 homolog (SEC13) belongs to the SEC13 family of WD-repeat proteins. SEC13 is required in the production of vesicles from the ER to the Golgi apparatus for the transport of proteins [40]. Its involvement in cancer has not yet been reported.

Serum albumin precursor is used for the synthesis of Human serum albumin (HSA), an endogenous plasma protein and it is the main component of the blood transport system. HSA transports and binds with water, hormones, fatty acids, metal ions and drugs. It also maintains blood osmotic pressure and $\mathrm{pH}$ besides acting as antioxidant 
in removing reactive oxygen species in the blood plasma [41]. Nevertheless, HSA levels and characteristics in cancer cells might have been modified from normal HSA [42]. The albumin portion of HSA exerts a growth inhibition in breast cancer cells that may affect cell proliferation by modulating the activities of growth factors [43]. HSA was a potent stimulator of estrone sulphatase activity and therefore contributes directly to the high estrogen concentrations found in breast cancer [44]. In addition to breast cancer, HSA was found accumulated in tumours in ovarian cancer [45].

\section{Conclusion}

The major limitation of this study is its sample size, nevertheless, the proteins identified were found consistently upregulated in the patients tested and their upregulations were significant statistically $(P<.05)$ indicating their possible roles in the development of the disease. The expressions levels of SEC13-like 1 (isoform b), calreticulin, 14-3-3 protein zeta, and 14-3-3 protein eta were found significantly related to certain stages or grades of the IDC breast tumour tissues. In view of their consistent (100\%) upregulated expression in specific stage or grade of IDC breast tumour, their potential use as biomarkers for diagnosis, prognosis, or treatment of IDC breast cancer is undeniable.

\section{Abbreviations}

IDC: Infiltrating ductal carcinoma

2D-PAGE: Two-dimensional polyacrylamide gel electrophoresis

AEBSF: $\quad 4$-(2-Aminoethyl) benzenesulfonyl fluoride

TCA: Trichloroacetic acid

DTT: $\quad$ Dithiothreitol

CHAPS: 3-[(3-Cholamidopropyl)dimethylammonio]1-propanesulfonate

SDS-PAGE: Sodium dodecyl sulfate polyacrylamide gel electrophoresis

CBR-250: Coomassie Brilliant Blue 250

LC/MS/MS: Liquid chromatography tandem mass spectrometry

ACN: Acetonitrile

$\mathrm{NH}_{4} \mathrm{HCO}_{3}$ : Ammonium bicarbonate

BSA: $\quad$ Bovine serum albumin

PBS: $\quad$ Phosphate buffered saline

HRP: $\quad$ Horseradish peroxidase

4CN: 4-chloro napthtol.

\section{Acknowledgments}

The authors thank the Ministry of Science, Technology and Innovation Malaysia for providing a Grant (project no.: 02-01-05-SF0353) to fund this project, the Ministry of Health, Malaysia for providing the tissues, and human ethical clearance for conducting this research.

\section{References}

[1] American Cancer Society, "How many women get breast cancer?" http://www.cancer.org/docroot/CRI/content/CRI_2_2_ 1X_How_many_people_get_breast_cancer_5.asp.

[2] World Health Organization, "Cancer: Fact Sheet," http://www .who.int/entity/mediacentre/factsheets/fs297/en/index.html.

[3] G. C. C. Lim and Y. Halimah, Second Report of the National Cancer Registry 2003: Cancer Incidence in Malaysia 2003, National Cancer Registry, Kuala Lumpur, Malaysia, 2004.

[4] J. G. Molland, M. Donnellan, N. C. Janu, H. L. Carmalt, C. W. Kennedy, and D. J. Gillett, "Infiltrating lobular carcinomaa comparison of diagnosis, management and outcome with infiltrating duct carcinoma," The Breast, vol. 13, no. 5, pp. 389396, 2004.

[5] Y. Peng, Y. Li, L. L. Gellert et al., "Androgen receptor coactivator p44/Mep50 in breast cancer growth and invasion," Journal of Cellular and Molecular Medicine. In press.

[6] R. K. Rasmussen, H. Ji, J. S. Eddes et al., "Two-dimensional electrophoretic analysis of human breast carcinoma proteins: mapping of proteins that bind to the $\mathrm{SH} 3$ domain of mixed lineage kinase MLK2," Electrophoresis, vol. 18, no. 3-4, pp. 588-598, 1997.

[7] M. R. Wilkins, C. Pasquali, R. D. Appel et al., "From proteins to proteomes: large scale protein identification by two-dimensional electrophoresis and amino acid analysis," Bio/Technology, vol. 14, no. 1, pp. 61-65, 1996.

[8] P. H. O'Farrell, "High resolution two dimensional electrophoresis of proteins," The Journal of Biological Chemistry, vol. 250, no. 10, pp. 4007-4021, 1975.

[9] C. S. Giometti, S. L. Tollaksen, C. Chubb, C. Williams, and E. Huberman, "Analysis of proteins from human breast epithelial cells using two-dimensional gel electrophoresis," Electrophoresis, vol. 16, no. 7, pp. 1215-1224, 1995.

[10] F. Le Naour, D. E. Misek, M. C. Krause et al., "Proteomicsbased identification of RS/DJ-1 as a novel circulating tumour antigen in breast cancer," Clinical Cancer Research, vol. 7, no. 11, pp. 3325-3327, 2001.

[11] D.-Q. Li, L. Wang, F. Fei et al., "Identification of breast cancer metastasis-associated proteins in an isogenic tumor metastasis model using two-dimensional gel electrophoresis and liquid chromatography-ion trap-mass spectrometry," Proteomics, vol. 6, no. 11, pp. 3352-3368, 2006.

[12] M. J. Page, B. Amess, R. R. Townsend et al., "Proteomic definition of normal human luminal and myoepithelial breast cells purified from reduction mammoplasties," Proceedings of the National Academy of Sciences of the United States of America, vol. 96, no. 22, pp. 12589-12594, 1999.

[13] K. Williams, C. Chubb, E. Huberman, and C. S. Giometti, "Analysis of differential protein expression in normal and neoplastic human breast epithelial cell lines," Electrophoresis, vol. 19, no. 2, pp. 333-343, 1998.

[14] P. Alfonso, A. Núñez, J. Madoz-Gurpide, L. Lombardia, L. Sánchez, and J. I. Casal, "Proteomic expression analysis of colorectal cancer by two-dimensional differential gel electrophoresis," Proteomics, vol. 5, no. 10, pp. 2602-2611, 2005.

[15] R. Chen, S. Pan, T. A. Brentnall, and R. Aebersold, "Proteomic profiling of pancreatic cancer for biomarker discovery," Molecular and Cellular Proteomics, vol. 4, no. 4, pp. 523-533, 2005.

[16] D. B. Friedman, S. Hill, J. W. Keller et al., "Proteome analysis of human colon cancer by two-dimensional difference gel electrophoresis and mass spectrometry," Proteomics, vol. 4, no. 3, pp. 793-811, 2004. 
[17] P. R. Jungblut, U. Zimny-Arndt, E. Zeindl-Eberhart et al., "Proteomics in human disease: cancer, heart and infectious diseases," Electrophoresis, vol. 20, no. 10, pp. 2100-2110, 1999.

[18] M. R. Emmert-Buck, J. W. Gillespie, C. P. Paweletz et al., "An approach to proteomic analysis of human tumors," Molecular Carcinogenesis, vol. 27, no. 3, pp. 158-165, 2000.

[19] F. J. Esteva and G. N. Hortobagyi, "Prognostic molecular markers in early breast cancer," Breast Cancer Research, vol. 6, no. 3, pp. 109-118, 2004.

[20] National Cancer Institute, "Breast cancer staging," http://www .cancer.gov/cancertopics/wyntk/breast/page9.

[21] National Cancer Institute, "Tumor grade: questions and answers," http://www.cancer.gov/cancertopics/factsheet/Detection/tumor-grade.

[22] A. Tsugita and M. Kamo, "2-D electrophoresis of plant proteins," in Methods in Molecular Biology, A. J. Link, Ed., vol. 112 of 2-D Proteome Analysis Protocols, pp. 95-98, Humana Press, Totowa, NJ, USA, 1999.

[23] U. K. Laemmli, "Cleavage of structural proteins during the assembly of the head of bacteriophage T4," Nature, vol. 227, no. 5259, pp. 680-685, 1970.

[24] M. I. Othman, M. I. A. Majid, M. Singh, S. Subathra, L. Seng, and L.-H. Gam, "Proteomics of Grade 3 infiltrating ductal carcinoma in Malaysian Chinese breast cancer patients," Biotechnology and Applied Biochemistry, vol. 52, no. 3, pp. 209219, 2009 .

[25] M. Lauriere, "A semidry electroblotting system efficiently transfers both high- and low-molecular-weight proteins separated by SDS-PAGE," Analytical Biochemistry, vol. 212, no. 1, pp. 206-211, 1993.

[26] S. Liang, M. Singh, and L.-H. Gam, "The differential expression of aqueous soluble proteins in breast normal and cancerous tissues in relation to ethnicity of the patients; Chinese, Malay and Indian," Disease Markers, vol. 28, no. 3, pp. 149-165, 2010.

[27] P. D. Nash, M. Opas, and M. Michalak, "Calreticulin: not just another calcium-binding protein," Molecular and Cellular Biochemistry, vol. 135, no. 1, pp. 71-78, 1994.

[28] L. Bini, B. Magi, B. Marzocchi et al., "Protein expression profiles in human breast ductal carcinoma and histologically normal tissue," Electrophoresis, vol. 18, no. 15, pp. 2832-2841, 1997.

[29] K. Chahed, M. Kabbage, B. Hamrita et al., "Detection of protein alterations in male breast cancer using two dimensional gel electrophoresis and mass spectrometry: the involvement of several pathways in tumorigenesis," Clinica Chimica Acta, vol. 388, no. 1-2, pp. 106-114, 2008.

[30] B. Franzén, S. Linder, A. A. Alaiya et al., "Analysis of polypeptide expression in benign and malignant human breast lesions," Electrophoresis, vol. 18, no. 3-4, pp. 582-587, 1997.

[31] A. Aitken, " $14-3-3$ and its possible role in co-ordinating multiple signalling pathways," Trends in Cell Biology, vol. 6, no. 9, pp. 341-347, 1996.

[32] H. Fu, R. R. Subramanian, and S. C. Masters, "14-3-3 Proteins: structure, function, and regulation," Annual Review of Pharmacology and Toxicology, vol. 40, pp. 617-647, 2000.

[33] P. Russell, "Checkpoints on the road to mitosis," Trends in Biochemical Sciences, vol. 23, no. 10, pp. 399-402, 1998.

[34] E. M. C. Skoulakis and R. L. Davis, "14-3-3 Proteins in neuronal development and function," Molecular Neurobiology, vol. 16 , no. 3 , pp. 269-284, 1998.
[35] M. B. Yaffe, "How do 14-3-3 proteins work?-gatekeeper phosphorylation and the molecular anvil hypothesis," FEBS Letters, vol. 513, no. 1, pp. 53-57, 2002.

[36] H. Hermeking, "The 14-3-3 cancer connection," Nature Reviews Cancer, vol. 3, no. 12, pp. 931-943, 2003.

[37] G. Tzivion, Z. Luo, and J. Avruch, "A dimeric.14-3-3 protein is an essential cofactor for Raf kinase activity," Nature, vol. 394, no. 6688, pp. 88-92, 1998.

[38] A.-S. Vercoutter-Edouart, J. Lemoine, X. Le Bourhis et al., "Proteomic analysis reveals that $14-3-3 \sigma$ is down-regulated in human breast cancer cells," Cancer Research, vol. 61, no. 1, pp. 76-80, 2001.

[39] L. Zang, D. P. Toy, W. S. Hancock, D. C. Sgroi, and B. L. Karger, "Proteomic analysis of ductal carcinoma of the breast using laser capture microdissection, LC-MS, and 16O/18O isotopic labeling," Journal of Proteome Research, vol. 3, no. 3, pp. 604612, 2004.

[40] B. L. Tang, F. Peter, J. Krijnse-Locker, S. H. Low, G. Griffiths, and W. Hong, "The mammalian homolog of yeast Sec13p is enriched in the intermediate compartment and is essential for protein transport from the endoplasmic reticulum to the Golgi apparatus," Molecular and Cellular Biology, vol. 17, no. 1, pp. 256-266, 1997.

[41] M.-K. Cha and I.-H. Kim, "Glutathione-linked thiol peroxidase activity of human serum albumin: a possible antioxidant role of serum albumin in blood plasma," Biochemical and Biophysical Research Communications, vol. 222, no. 2, pp. 619625, 1996.

[42] A. Gurachevsky, E. Muravskaya, T. Gurachevskaya, L. Smirnova, and V. Muravsky, "Cancer-associated alteration in fatty acid binding to albumin studied by spin-label electron spin resonance," Cancer Investigation, vol. 25, no. 6, pp. 378383, 2007.

[43] I. Laursen, P. Briand, and A. E. Lykkesfeldt, "Serum albumin as a modulator on growth of the human breast cancer cell line, MCF-7," Anticancer Research, vol. 10, no. 2 A, pp. 343-351, 1990.

[44] A. Purohit, D. Y. Wang, M. W. Ghilchik, and M. J. Reed, "Regulation of aromatase and sulphatase in breast tumour cells," Journal of Endocrinology, vol. 150, pp. S65-S71, 1996.

[45] E. F. Petricoin III, A. M. Ardekani, B. A. Hitt et al., "Use of proteomic patterns in serum to identify ovarian cancer," The Lancet, vol. 359, no. 9306, pp. 572-577, 2002. 

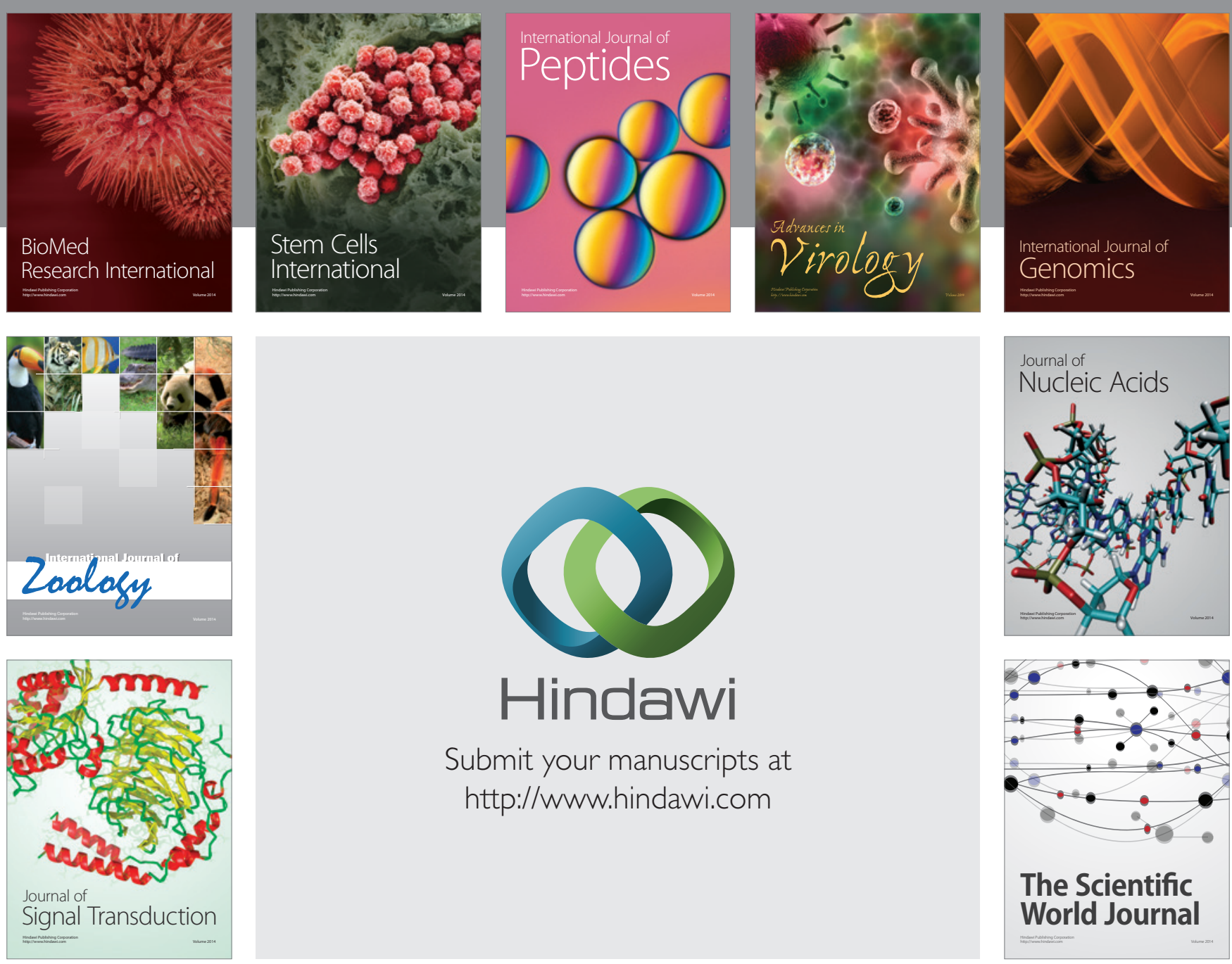

Submit your manuscripts at

http://www.hindawi.com
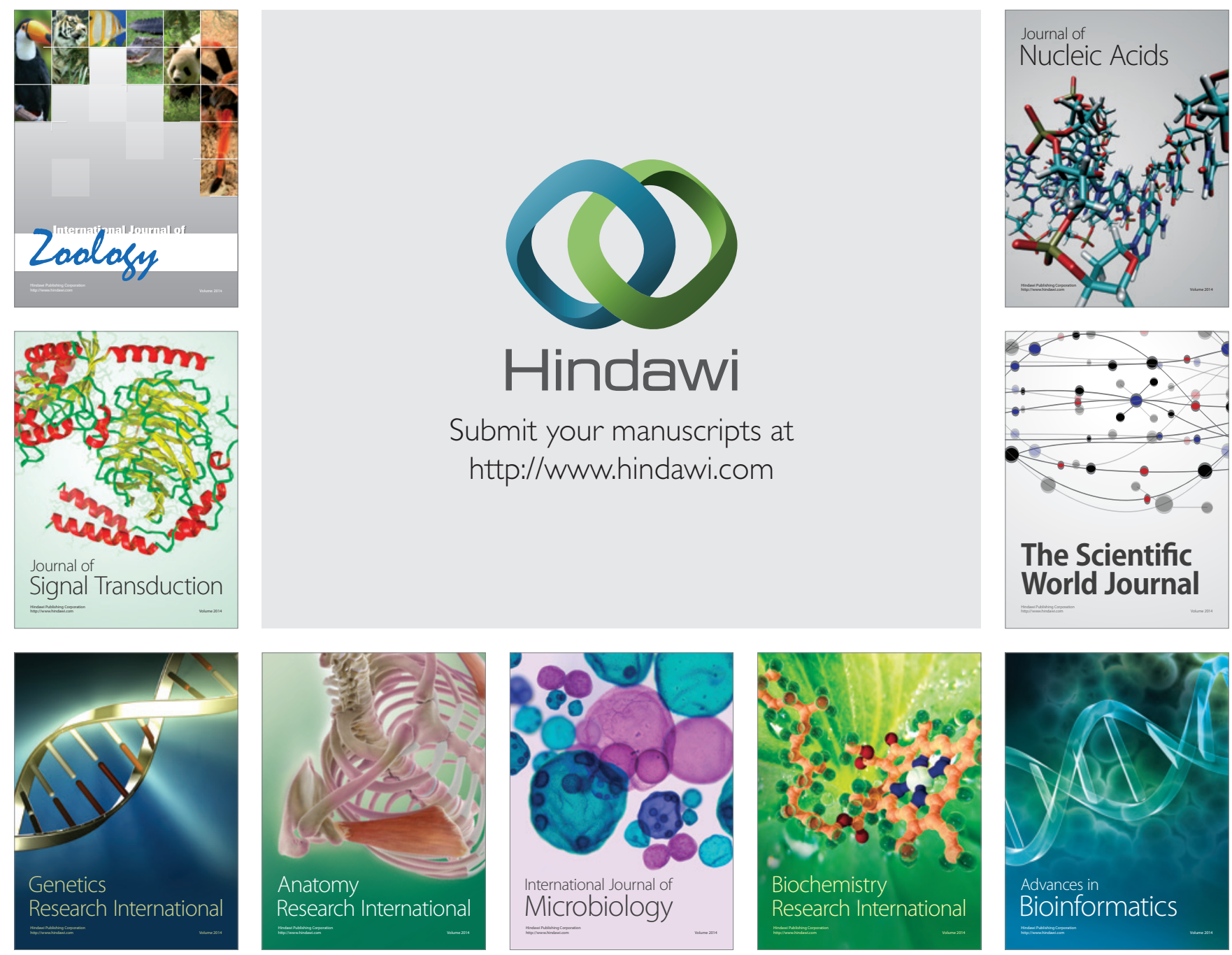

The Scientific World Journal
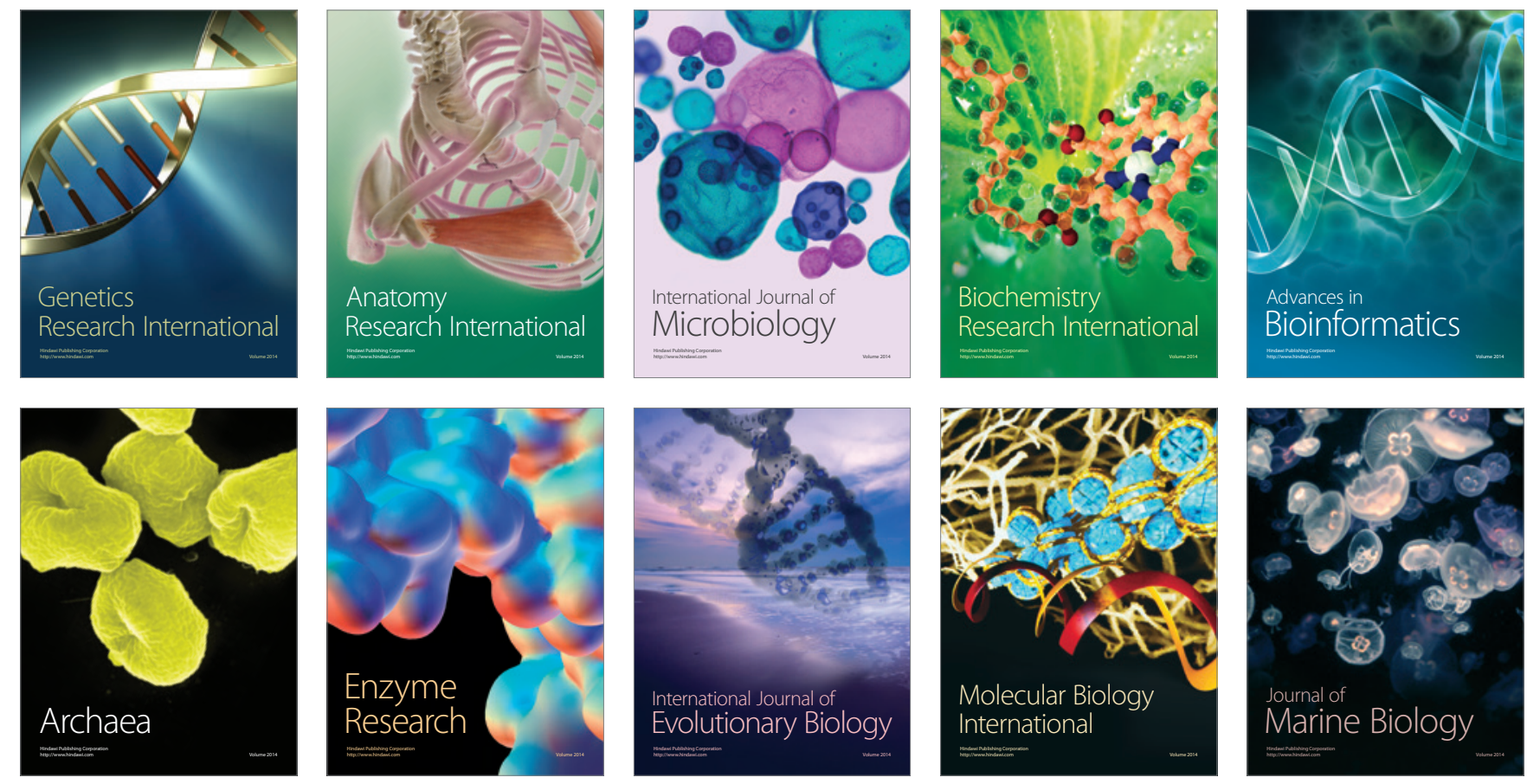